\title{
KURSI PEMILU: SASTRA DAN BUDAYA DEMOKRASI PRAREFORMASI
}

\author{
I Nyoman Suaka \\ Prodi Pendidikan Bahasa dan Sastra Indonesia \\ FPBS IKIP Saraswati \\ E-mail: imansuaka@yahoo.co.id
}

\begin{abstract}
Abstrak
Novel Kursi Pemilu (1982) karya Sinansari Ecip dibahas dengan latar belakang politik tentang pemilihan kepala desa (Pilkades). Pada tahun 1970-an, politik negara berlangsung dalam pengaruh kekuasaan Orde Baru. Pemasalahannya adalah bagaimana pelaksanaan pilkades sebagai perwujudan demokrasi di tingkat bawah dan bagaimana kekuasaan politik itu dijalankan sebagai realitas politik pada zamannya? Teori yang digunakan adalah teori hegemoni dari Antonio Gramsci dengan menggunakan pendekatan hermeneutika (interpretatif) untuk mengungkapkan kekuatan teks sastra. Hasil analisis menunjukkan bahwa kekuasaan politik orde baru sangat kuat mengakar di masyarakat. Kontestan Pemilu yang dilukiskan dalam novel Kursi Pemilu seperti, Goljo, Golning, dan Golrah tiada lain adalah akronim dari Golongan hijau (goljo), Golongan kuning (Golning), dan Golongan merah (Golrah). Goljo identik dengan Partai Persatuan Pembangunan (PPP), Golning serupa dengan Golkar dan Golrah adalah Partai Demokrasi Indonesia (PDI). Tafsir itu semakin akurat kalau dihubungkan dengan basis pendukung masing-masing golongan. Goljo dalam novel itu didukung oleh alim ulama, pesantren, dan golongan tua yang taat beribadah. Golning tiada lain adalah barisan aparat pemerintah dari tingkat desa, camat, bupati, dan seterusnya. Golrah mendapat simpati dari sebagian besar generasi muda yang sangat mendambakan perubahan dan antikemapanan. Menjelang reformsi kondisi ini banyak digugat karena model demokrasi seperti itu lebih bersifat sentralistik untuk melanggengkan kekuasaan golongan tertentu.
\end{abstract}

Kata kunci: novel, demokrasi, pemilu.

\section{PENDAhULUAN}

Sebuah novel yang secara utuh mengambil latar tentang Pemilu adalah karya Sinansari Ecip yang berjudul Kursi Pemilu. Novel ini diterbitkan tahun 1982, mengisahkan pergolakan masyarakat di sebuah desa saat menghadapi Pemilihan Kepala Desa (Pilkades). Alur ceritanya mengisahkan suasana masyarakat Desa Gondomayi, dekat kota Malang, Jawa Timur dalam menentukan aspirasi politiknya memilih kepala desa baru. Suasana kasak-kusuk, kecurangan Pilkades, ketidakjujuran penghitungan suara, serta pemilu susulan dilukiskan oleh pengarang.

Pemilu tingkat desa dalam novel itu tidak kalah serunya dengan pemililhanbupati, gubernur dan presiden yang dialami langsung oleh masyarakat era reformasi.Terlebih lagi suasana desa saat kampanye penuh dengan desas-desus dan intimidasi.Tiga orang yang mewakili tiga dusun di Desa Gondomayi bersaing dalam merebutkan kursi kepala desa. Jabatan Kades merupakan jabatan terhormat di desa-desa di Jawa, baik dari segi pribadi, keluarga, kekuasaan, maupun material sebab seorang kades secara otomatis berhak mengelola tanah bengkok seluas empat puluh hektar. Hasil sekali panen saja 
sudah bisa membeli satu mobil mewah, demikian pandangan masyarakat. Pengarang Sinansari Ecip mampu mengangkat realitas pemilihan kades pada zamannya. Cerita novel ini mampu menjadi nosatalgia politik kalau dikaitkan dengan budaya politik sebagai bentuk hegemoni dari pemerintah yang berkuasa saat itu.

Konsep hegemoni memainkan peranan penting dalam perkembangan kajian budaya dan merupakan salah satu konsep kunci yang paling ramai diperdebatkan selama tahun 1970 dan 1980-an. Kajian budaya mengambil dan mengembangkan konsep hegemoni dari Antonio Gramsci. Menurut teori ini, ada seikat makna dalam budaya manapun yang bisa disebut sebagai makna-makna yang memerintah (governing). Proses membuat, menjaga dan mempertahankan serta memproduksi seperangkat makna. Ideologi dan paktek yang bersifat otoritatif inilah yang disebut hegemoni (Barker, 2015 : 119)

Bagi Gramsci (2015:119), hegemoni mengimplikasikan sebuah situasi dimana "block historis" dari kelas yang berkuasa melakukan otoritas sosial dan kepemimpinannya terhadap kelas-kelas yang berada di bawahnya (sub ordinat) lewat sebuah kombinasi kekuatan, dan lebih penting lagi persetujuan. Sebagai akibatnya, Gramsci membuat perjuangan dan konflik ideologis dalam masyarakat sipil sebagai arena sentral politik budaya, dimana analisis yang menyingkap hegemoni sebagai cara melihat kekuatan relevan.

Istilah hegemoni terkait budaya politik berkembang luas di Indonesai. Melalui bahasa yang sederhana, Gaffar (1983:81) menyebutkan bahwa kebudayaan politik mengatur siapa yang berbicara dengan siapa, dan siapa yang mempengaruhi. Kebudayaan politik juga menentukan apa yang dibicarakan dalam hubungan politik, dan bagaimana pengaruh-pengaruh hubungan itu. Tetapi perlu diingat, kebudayaan politik juga menata mekanisme lembaga-lembaga formal yang ada.

\section{METODE}

Teks sastra tidak bisa berdiri sendiri. Makna teks ditentukan oleh konteksnya yang menyangkut situasi dan kondisi jaman. Sebuah novel tidak bisa memberikan makna secara maksimal kalau dibaca teksnya saja. Novel sebagai karya sastra perlu ditafsirkan maknanya. Dalam kajian ilmiah, analisis teks dapat menggunakan metode interpretatif (hermeneutika). Menurut antropolog Geertz (1999), pendekatan interpretatif adalah menyahihkan diri, atau sebagai sesuatu yang disahkan dengan kepekaan-kepekaan yang dianggap maju dari orang lain yang menjelaskannya.

Interpretasi sangat penting dilakukan dalam analisis novel sebab metode itu memberikan pemahaman antara khayalan pengarang dengan realitas yang terjadi di tengah-tengah masyarakat. Seberapa jauh karya itu berfungsi sebagai cermin masyarakat dan sebaliknya seberapa jauh unsurunsur masyarakat diserap ke dalam karya sastra. Pendekatan interpretatif ini sering disebut dengan istilah hermeneutic.Pada dasarnya hermeneutic berhubungan dengan bahasa. Oleh karena itu, metode interpretatif sangat membantu, memahami novel lebih mendalam karena novel menggunakan media bahasa sebagai alat pengungkapannya

Isu sentral bagi hermeneutika adalah terciptanya makna dan sejauh mana makna ini memang terdapat dalam teks atau/ dan diciptakan oleh pembaca (penafsir). Menurut Bekker (2003:121) dalam hermeneutika kontemporer, pemahaman dan makna diwujudkan oleh pembaca actual dalam sebuah proses penafsiran teks yang tergantung pada gugus makna yang memang tersurat dalam teks sekaligus aktivitas pembaca itu sendiri. Mengacu pada pendapat Bakker tersebut maka dilakukan pembacaan teks terlebih dahulu, novel Kursi Pemilu, kemudian dipahami dan ditafsirkan makna teks ke dalam konteksnya.

\section{PEMBAHASAN}

\subsection{Ringkasan Cerita}

Kisah Kursi Pemilu bermain di Desa Gondomayi, sebuah wilayah kecil di dataran tinggi yang subur dekat Kota Malang. Kepala desa (kades) yang populer disebut Pak Petinggi itu diceritakan sudah tua dan sakit-sakitan. Desa ini didukung oleh tiga dusun/dukuh, yakni dusun Grinhil, Kramtung, 
dan Gondomayi. Kades, seperti layaknya struktur pemerintahan desa, didampingi seorang sekretaris desa (Pak Carik) yang merangkap sebagai bendahara desa. Dalam soal pemerintahan, Pak Carik tampak lebih mampu, lincah, dan cekatan dibandingkan dengan Pak Kades. Walaupun demikian, setiap keputusan selalu ada di tangan Kades.

Tiba-tiba Pak Kades meninggal. Masyarakat kaget sebab siang harinya Pak Kades masih sempat ke kantor. Hal itu dimanfaatkan oleh Pak Carik untuk menyusun strategi agar dapat menggantikan posisi Pak Petinggi. Meninggalnya Pak Kades segera dilaporkan ke Pak Camat. Sebagai sekretaris desa, Pak Camat menunjuk Pak Carik menjadi panitia pemilihan kades sarnpai tugas-tugasnya selesai dan kades definitif dilantik.

Dalam bursa pencalonan kades, terdaftar tiga orang calon yang siap bertarung dalam Pemilu Desa Gondomayi. Mereka adalah Kamituwo Grinhil wakil Goljo, Pak Carik dari Golning, dan Kamituwo Kramtung dari dusun Kramtung mewakili Golrah. Peta kekuatan masing-masing calon itu berbeda dan memiliki pendukung fanatik. Goljo didukung oleh alim ulama, pesantren dan masyarakat yang taat beribadah. Golning didukung oleh aparat desa dan tokoh-tokoh masyarakat, sedangkan Golrah memiliki basis anak muda dan generasi muda lainnya yang memperjuangka perubahan.

Ketiga calon itu berusaha sekuat tenaga memengaruhi massa, termasuk mendekati calon pemilih yang jelas-jelas berseberangan dengan dirinya. Caranya, dengan trik-trik politik, permainan uang dan rayuan, serla intimidasi untuk menjatuhkan kepribadian lawan poiitiknya. Pernah suatu ketika Pak Carik calon dari Golning memanfaatkan kemolekan seorang janda di Desa Gondomayi untuk menjatuhkan calon Goljo. Janda yang cantik dan pintar merayu itu.menyelinap di malam hari masuk ke kamar Kamituwo Grinhil (Goljo). Saat itu seperti biasanya, calon kades itu tidur terpisah dengan istrinya sehingga mereka berdua leluasa mengisi malam itu.

Keesokan harinya masyarakat Gondomayi ribut, penuh dengan gosip membicarakan Kamituwo dengan janda tadi. Tidak bisa dibendung lagi, istrinya marah-marah dan mengadukan permasalahannya kepada istri-istri pejabat desa. Kondisi ini jelas sangat menguntungkan Pak Carik karena pendukungnya kian bertambah. Posisi Pak Carik semakin kuat. Saat kampanye ia berjanji kepada masyarakat Grinhil akan segera membangun mesjid dan gereja di dusun itu yang diklaim sebagai terbesar di Asia Tenggara. Segala keperluan upacara keagamaan akan ditanggung oleh desa melalui kas desa. Tentu saja janji-janji kampanye itu disambut dengan gembira. Di Dusun Kramtung, Pak Carik berjanji akan membangun balai pertemuan yang megah dengan kaca jendela tembus pandang untuk menampung kegiatan kesenian dan olah raga bagi generasi muda. Selain itujuga dibuka kursus kecantikan, jalan becek akan diaspal dengan beton. Demikian kampanye Pak Carik yang mendapat sambutan meriah karena visi dan misinya itu sesuai dengan keinginan generasi muda di Dusun Kramtung.

Pada hari pencoblosoan, dukungan yang tampak lebih besar justru kepada Goljo dan Golrah. Masyarakat banyak menilai, wakil dari Goljo akan memenangkan Pemilu Kades itu, menyusul Golrah dan Golning. Argumentasi itu terlihat dari suara yang dimasukkan ke kotak Goljo. Pemungutan suara menggunakan besi paku, setiap pemilih memasukkan satu besi paku. Di sisi lain, sekitar seratus orang pemilih jelas-jelas menyatakan diri Golput, tidak memilih karena tidak percaya dengan kemampuan dan komitmen para calon. Anehnya azas Pemilu Desa Gondomayi tidak menggunakan azas luber, tetapi Lubetira yaitu kependekan dari langsung, umum, bebas, dan tidak rahasia.

Berdasarkan hasil perhitungan suara, Calon Goljo yang dipastikan menang mutlak, ternyata dikalahkan oleh Pak Carik dari Golning dengan suara tipis. Perolehan suara Pak Carik 2367 suara, Goljo 2364 suara, dan Golrah 611 suara. Hasil itu diprotes oleh massa Goljo yang menilai Pemilu curang, tidak jujur, dan penuh rekayasa. Protes itu ditujukan kepada Golning karena Pak Carik selain sebagai calon Golning juga sebagai sekretaris dan merangkap panitia pemilihan Kades. Suasana berubah menjadi unjuk rasa karena pendukung Goljo tidak puas. Tiba-tiba Pak Camat yang 
menyaksikan langsung pemilihan itu berusaha mengendalikan emosi massa. Untuk meredam suasana panas, Pak Camat mengajak massa untuk menyanyikan lagu kebangsaan Desa Gondomayi yaitu "Satu Desa Satu Sungai".

Pemilu Kades tidak sah, beberapa hari lagi akan diadakan Pemilu ulang.Pak Carik kembali menghubungi Pak Camat dan istrinya agar dapat mcmbantu menyukseskan dirinya supaya tetap terpilih sebagai kades. Secara moral, Pak Camat juga harus menyukseskan Pak Carik sebab kalau tidak demikian, jabatan sebagai camat akan dicopot. Intervensi seperti itu sangat dirasakan oleh masyarakat.Terlebih lagi Pemilu itu bukan lagi ditentukan oleh jumlah suara terbesar, tetapi keputusan tertinggi ada di tangan wedana atau bupati.Bisa saja suara yang jumlahnya lebih kecil dilantik menjadi kades, asal sehaluan dan segolongan dengan bupati. Hal ini dibenarkau oleh Pak Camat. Mendengar hal itu, salah seorang massa berteriak, tidak ada gunanya Pemilu. Pak Camat disuruh mengirim saja ketiga calon tanpa jumlah suara. Toh bupati yang akan memilihnya. Massa Goljo mendesak agar Pemilu diganti dengan Pemibu, yaitu pemilihan oleh bupati.

Hasil Pemilu kedua juga dimenangkan oleh Pak Carik, namun tidak berhasil disahkan.Tiba-tiba wakil dari Goljo angkat bicara tentang kematian Pak Petinggi, ternyata pelakunya adalah Pak Carik. Calon yang ambisius itu, sengaja membubuhi arcenicum, suatu zat yang mematikan, ke dalam minuman kopi yang diminum Pak Petinggi.Saksi mata dan pembuktiannya diperkuat oleh anggota Pagarpraja (Hansip desa) dan seorang cucu Pak Petinggi.Pimpinan Golrah memperkuat protes Goljo tentang kematian Pak Petinggi.Pak Carik tersentak, segala usahanya tidak menghasilkan. Jabatan sebagai penguasa tunggal di desa Gondomayi dan harapan menguasai tanah bengkok lenyap dari tangannya.

Bupati segera mengumumkan keadaan desa melalui radio setempat. Bupati mengatakan telah terjadi penyelewengan jumlah paku sebagai tanda suara. Kedua peristiwa itu berhubungan erat. Untuk itu, Pak Carik ditangkap dan diadili. Sebagai Kades baru Desa Gondomayi, ditunjuk Pak
Wedana untuk menjaga stabilitas desa. Wedana adalah pejabat lebih tinggi dari camat, lebih rendah dari bupati.

\subsection{Sastra dan Citra Demokrasi}

Pengarang Sinansari Ecip dalam Kursi Pemilu, tampaknya berusaha secara maksimal mengangkat realitas masyarakat sekitar tahun 1970-1980. Waktu itu, dalam politik negara, pengaruh kekuasaan Orde Baru sangat kuat mengakar di masyarakat. Kontestan Pemilu yang dilukiskan dalam novel seperti Goljo, Golning, dan Golrah tiada lain merupakan akronim dari Golongan hijau (Goljo), Golongan kuning (Golning), dan Golongan merah (Golrah). Goljo identik dengan Partai Pcrsatuan Pembangunan (PPP), Golning serupa dengan Golkar dan Golrah adalah Partai Demokrasi Indonesia (PDI). Ketiga golongan ini dalam masa Orde Baru sebagai kontestan Pemilu.

Penafsiran itu semakin jelas lagi kalau dihubungkan dengan basis pendukung masingmasing golongan. Goljo dalam novel itu didukung oleh alim ulama, pesantren, dan golongan tua yang taat beribadah. Golning tiada lain adalah barisan aparat pemerintah dari tingkat bawah. desa, camat, bupati, PNS dan seterusnya. Golrah dapat simpati dari sebagian besar generasi muda yang sangat mendambakan perubahan. Dengan cermat, pengarang Sinansari Ecip juga mengungkapkan tentang Golput (golongan putih). Jumlahnya mencapai ratusan orang yang tidak menggunakan hak pilihnya. Suatu jumlah cukup besar untuk Pemilu tingkat desa. Secara realitas, istilah Golput itu juga populer di tahun 1980-an karena mereka tidak puas dengan tiga partai tadi. Dua partai lain, yaitu PPP dan PDI yang semestinya lebih berani mengoreksi pemerintah yang berkuasa saat itu, ternyata lebih sering menyelarnatkan diri untuk bergabung dengan Golkar dalam setiap keputusan politik.

Pengaruh Pak Camat dan Bupati seperti dikisahkan pengarang Sinansari Ecip sangat kuat dalam menentukan arah kebijakan di desa. Bahkan sejarahmencatat, seringkaliterjadidalampemilihan kades di tanah air, calon yang memperoleh jumlah suara terbanyak belum jaminan dilantik sebagai kades. Diperlukan penelitian ulang yang distilahkan 
dengan litsus (penelitian khusus). Hasil litsus ini dapat menggagalkan calon yang hampir jadi. calon lain, asal sehaluan dan segolongan serta seideologi dengan penguasa akhimya dilantik dengan tanpa menghadapi kendala. Situasi seperti itu berhasil direkam oleh pengarang Sinansari Ecip yang nama sebenamya adalah Sutiono, pengarang kelahiran Malang.

Politik demokrasi dalam Kursi Pemilu mencerminkan peta perpolitikan nasional di tahun 1970-an. Ketika itu pemilu dilaksanakan berdasarkan Undang-Undang Nomor 3 Tahun 1975 tentang Partai Politik dan Golkar, di mana dilakukan fusi partai-partai politik menjadi hanya dua partai (Partai Persatuan Pembangunan dan Partai Demokrasi Indonesia) dan satu Golongan Karya. Pesta demokrasi ketika itu sebagian besar dimenangkan oleh Golongan Karya. Pada saat itu meskipun pemilu terlaksana secara teratur setiap lima tahun, tetapi demokrasi belum berjalan sepenuhnya. Pemilu justru dipenuhi oleh kecurangan dan bersifat seolah-olah hanya sebagai formalitas dan sebagai informasi kepada dunia luar bahwa Indonesia telah melaksanakan pemilu dan praktik demokrasi dengan benar.

Kejayaan Orde Baru mengalami puncaknya saat pemilu tahun 1997 yang ditandai dengan kemenangan mutlak Golkar. Golkar satu-satunya peserta pemilu yang didukung secara finansial maupun secara politik oleh pemerintah untuk memenangkan pemilu dengan meraih suara terbanyak. Secara nasonal, berbagai cara dilakukan Presiden Soeharto untuk mempertahankan kekuasaannya dengan memenangkan Golkar dalam setiap pemilu, salah satunya dengan cara intimidasi. Lembaga-lembaga penyelenggaraan pemilu didominasi oleh pemerintah dan Golkar. Pegawai Negeri Sipil diharuskan memilih Golkar dengan cara menempatkan tempat pemungutan suara di kantor-kantor pemerintah (http:// kompasiana.com). Menjelang reformasi kondisi ini banyak digugat karena budaya demokrasi seperti itu hanya untuk melanggengkaan kekuasaan golongan tertentu.

Kini hampir tidak ada lagi ciri-ciri politik otoriter, seperti yang terjadi pada masa Orde Baru.
Setelah Pemilu 1999 praktik demokrasi sudah mulai berjalan sebagaimana mestinya. Pemilu dilakukan dengan azas langsung, umum, bebas, rahasia, jujur dan adil (Luberjurdil). Indonesia sudah memasuki era Reformasi, politiknya berbeda secara struktural dengan politik Orde Baru. Proses politik pemerintah sudah memasuki rezim demokratis dengan partisipasi rakyatnya secara aktif untuk menentukan pilihan. Pemerintah tidak lagi sebagai penyelenggara Pemilu yang rawan dengan kecurangan, tetapi telah ditangani oleh lembaga independen, yaitu Komisi Pemilihan Umum (KPU) dan Badan Pengawas Pemilu (Bawaslu).

\section{SIMPULAN}

Proses Pilkades dalam Kursi Pemilu merupakan cermin kondisi masyarakat yang telah dihegemoni oleh kekuasaan Orde Baru. Di sisi lain masyarakat menginginkan kebebasan dalam menemukan pemimpinnya sesuai dengan hati nurani. Akan tetapi, keputusan terakhir ada di tangan birokrasi pemerintah.Dalam novel dikisahkan terjadi kecurangan Pemilu yang menyebabkan desa dalam keadaan tidak aman sebagai bentuk resistensi masyarakat, yang tidak puas dengan pelaksaaan demokrasi Orde Baru Pengarang Sinansari Ecip berhasil menggarap novel itu dengan meramu fakta ke dalam dunia fiksi. Kursi Pemilu memberikan makna mencari kedudukan atau kekuasaan, sebab kata 'kursi' disini tidak terbatas berarti tempat duduk tetapi sebuah tahta jabatan/kedudukan. Walaupun berkisah di tingkat desa, akan tetapi novel ini identik dengan peta perpolitikan nasional pra reformasi. dengan dua partai (PPP, PDI) dan Golongan Karya (Golkar).

\section{DAFTAR PUSTAKA}

Barker, Chris. 2003. The Sage Dictionary of Cultural Studies. London : Sage Publication Ltd

Encip, Sinansari. 1982. Kursi Pemilu. Jakarta : Sinar Harapan.

http:/kompasiana.com. "Budaya Demokrasi dan Partiipasi Politik Indonesia Pada Masa Orde 
Baru,” Diunduh 14 Maret 2018.

https://guruppkn.com/demokras-era reformasi.

Diunduh 15 Maret 2018.

Fuller, Andy. 20011. Sastra dan Politik Membaca Karya-karya Seno Gumira Ajidarma. Yogajakarta : Insist Press.

Gaffar, Affan. 1983. Beberapa Aspek Pembangunan Politik. Jakarta : Rajawali.

Geertz, Clifford. 1999. Tafsir Kebudayaan (terjemahan Budi Hermawan). Yogjakarta : Kanisius.

Suaka, I.N. 2013. "Pemilihan Kepala Desa (Pilkades) dalam Novel: Refleksi Budaya Politik Era Orde Baru.” Makalah dalam Seminar KKL di Universitas Muhamadyah Malang, 19 Juni. 